\title{
Material on Canal and Railroad Construction
}

Along with the articles relative to the Erie Canal and the Boston and Albany Railroad, it seems appropriate to offer some general estimate of canal and railroad material available in the manuscript collection at Baker Library. The two most important groups in this field are the Baldwin papers, the gift of Mr. James R. Baldwin, and the Stabler papers, deposited with Baker Library by the Maryland Historical Society.

Considering, first, the Baldwin collection, we find papers relative to innumerable canal and railroad projects undertaken by various members of this engineering family. These papers cover the long period, I79I-I 860. Concerning canals, they include information on the Middlesex Canal, the Amoskeag Canal, the Shubenacadie Canal, and the Cape Cod Canal as well as some fifteen other canals for which there is only a folder or two of papers. The railroad material of this collection concerns the Boston Marine, Boston and Albany, Lowell, Boston and Worcester, Providence, Charlestown, Brattleboro, and Buffalo and Mississippi railroads.

The Stabler collection is likewise of great importance. It includes the papers of two able engineers - Isaac Briggs and James P. Stabler. Among the Isaac Briggs papers, 1817-1 823, are manuscripts relative to the Erie Canal and the canal from Baltimore to the Potomac. The papers of James P. Stabler, I829-1 837, concern the construction of the Baltimore and Ohio Railroad, the Wilmington and Susquehanna Railroad, and the Delaware and Maryland Railroad.

In addition to these two major collections there are a number of smaller groups. The S.M. Felton papers concern the construction of the Fitchburg, Boston and Maine, Vermont Central, and the Lowell and Lawrence railroads. The Strong and Chamberlain papers relate to the construction and operation of the Rutland and Washington Railroad. There are also a few papers on the Chester Valley Railroad in Pennsylvania, and the Connecticut and Passumpsic River Railroad.

Finally, there is an interesting group of papers on the Illinois Land Agency. This agency was established to aid in financing the construction of the Illinois Central Railroad. The papers relate to 
the various transactions in selling land for this purpose. This completes the list of manuscript material which relates to canal and railroad construction.

\section{Contributions to Source Material for Business History}

THERE is one type of source material for business history to which members of the Society could and should make valuable contributions. This is in the recording of the significant facts concerning the development of their own business concerns. After a man has spent the best years of his life and much of his talent and energy in administering a business enterprise, it would be of great value if he could sit down and, as clearly as possible, describe all sides of every problem which led to the formulation of important decisions, along with the results of the policies based on those decisions. By collecting such impressions over a period of years, there could be brought together a mass of information which would be important to the study of business history.

Already, two such pieces have come to the Society: Woolen Manufacturing in Amesbury, $1821-1852$ by Joshua Aubin and The Collins Company, I826-1867 by Samuel Watkinson Collins. The latter, a history of a company manufacturing axes, is particularly interesting, at this time, because of the great amount of space devoted to the discussion of various depression periods. The year 1833 brought not only financial problems, but labor difficulties as well and forms one of the most interesting portions of the record:

This was an eventful year. The panic in consequence of the Asiatic Cholera disarranged business and checked sale of our goods. Workmen were dissatisfied with our attempts to organize the business more economically and we found it impossible to make sales and collections fast enough to meet our expenses, especially at the Hartford. Bank, and was disposed to curtail the loans made to us on accomodation paper. D. C. Collins was a Director in the Phoenix Bank but our loans there were not large.

As much had been said about our stringent and illiberal contracts with workmen in the first years of the business, the "temperance principles" and rigid rates. I will transcribe here a copy of a correspondence with 